\title{
Pengaruh Sharia Marketing terhadap Loyalitas Anggota KSPPS BMT Walisongo Semarang
}

\author{
Nurudin \\ UIN Walisongo Semarang \\ nurudin@walisongo.ac.id
}

\begin{abstract}
Islamic business has always been held based on the principle of justice and equilibrium. Remembering that business now is very competitive, many financial institutions in doing their marketing activities deviate from sharia principles only to meet the needs, desires and to satisfy customers so that they do not move to other places to get a lot of profit. The development of number of members in KSPPS BMT Walisongo Semarang experienced an increase in deposit products and decline in financing products in 2016.The formulation of the problem in this research is how the influence of sharia marketing (product, price, place, promotion) toward the loyalty of members of KSPPS BMT Walisongo Semarang. The purpose of this research is to know the influence of sharia marketing (product, price, place, and promotion) toward the loyalty of KSPPS BMT Walisongo Semarang.This research is a field research with quantitative approach. The population of this research is all members of KSPPS BMT Walisongo Semarang which is amounted 2,469. Sampling technique used in this research is Slovin formula amounted 100 people who will be selected to be respondents with certain criteria. The method used in this research is purposive sampling. The technique of analyzing the data is simple regression.From the simultaneous calculation results obtained t count is equal to (6,558) and $p$ value (sig) is equal to 0.000 below 5\% which means that there is significant influence between sharia marketing (product, price, place, promotion) toward member loyalty. The four dimensions of sharia marketing have a positive and significant influence on member loyalty. But in this study, products have a significant influence on loyalty members.
\end{abstract}

Keywords: sharia marketing (product, price, place, promotion); member loyalty. Abstrak

Bisnis Islami pada hakikatnya selalu memegang asas keadilan dan keseimbangan. Mengingat semakin ketatnya persaingan bisnis sekarang ini, banyak lembaga keuangan dalam melakukan kegiatan pemasarannya menyimpang dari prinsip syariah hanya untuk memenuhi kebutuhan, keinginan dan memuaskan pelanggan agar mereka tidak beralih ke tempat lain serta untuk mendapatkan keuntungan yang banyak. Perkembangan jumlah anggota di KSPPS BMT Walisongo Semarang mengalami peningkatan pada produk simpanan dan mengalami penurunan pada produk pembiayaan pada tahun 2016. Rumusan masalah dalam penelitian ini adalah bagaimana pengaruh sharia marketing (produk, harga, tempat, promosi)terhadap loyalitas anggota KSPPS BMT Walisongo Semarang.Tujuan dalam penelitian ini adalah untuk mengetahui pengaruh sharia marketing (produk, harga, tempat, promosi) terhadap loyalitas anggota KSPPS BMT Walisongo Semarang. Penelitian ini merupakan penelitian lapangan dengan pendekatan kuantitatif. Populasi penelitian ini adalah seluruh anggota KSPPS BMT Walisongo Semarang yang berjumlah 2.469. Pengambilan sampel dengan menggunakan rumus Slovin berjumlah 100 orang dengan didukung penelitian terhadap anggota yang akan dipilih menjadi responden dengan kriteria-kriteria tertentu. Metode dalam penelitian ini adalah purposive sampling.Teknik analisa yang digunakan adalah regresi sederhana. Dari hasil 
perhitungan secara simultan diperoleh t hitung sebesar $(6,558)$ dan $p$ value ( $\mathrm{sig}$ ) sebesar 0,000 dibawah 5\% yang berarti ada pengaruh yang signifikan antara sharia marketing (produk, harga, tempat, promosi) terhadap loyalitas anggota. Keempat dimensi dalam sharia marketing sama-sama memiliki pengaruh yang positif dan signifikan terhadap loyalitas anggota. Namun dalam penelitian ini produk yang lebih memiliki pengaruh yang besar terhadap loyalitas anggota.

Kata Kunci: sharia marketing (produk, harga, tempat, promosi); loyalitas anggota

\section{PENDAHULUAN}

Bisnis adalah bagian yang tidak terpisahkan dari kehidupan manusia. Kegiatan memenuhi kebutuhan hidup adalah kewajiban bagi seluruh umat muslim dan harus selalu berada di jalan yang lurus. Oleh sebab itu tujuan utama dari bisnis adalah mencapai ridha Allah SWT melalui aktivitas duniawi. Kegiatan memenuhi kebutuhan hidup ini merupakan kecenderungan alamiah dalam diri manusia untuk hidup dalam kenyamanan secara material (Alma \& Priansa, 2009: 1).

Persoalan bisnis akan terus berkembang dan meningkat. Oleh karenanya peningkatan kemampuan untuk lebih kompetitif dalam memutar roda bisnis mutlak diperlukan agar manusia bisa mempertahankan keberlangsungan usahanya dalam situasi kompetisi yang semakin ketat. Kuatnya persaingan membuat seleksi alamiah yang mengarah pada yang kuat yang bertahan. Keberhasilan akan digapai oleh pelaku bisnis dan perusahaan yang paling mampu menyesuaikan diri dengan persyaratan lingkungan saat ini, yaitu mereka yang sanggup memberikan apa yang siap dibeli masyarakat. Oleh karenanya, tidak jarang demi keuntungan, banyak yang nekad menggunakan cara-cara yang batil. Mencari, memelihara dan mempertahankan bisnis dengan berbekal ilmu bisnis buatan kapitalis dan sosialis yang lepas dari nilai tauhid yang haq mengakibatkan mereka jauh dari Allah, tidak mendapat berkah dan akhirnya mengantarkan mereka pada kehancuran (Hasan, 2009: 1).

Dalam hal inilah etika mempunyai peranan yang sangat penting dalam menjalankan bisnis. Dengan selalu berlandaskan etika dalam mengelola bisnis, ada jaminan bahwa roda bisnis akan berjalan dengan baik dan tentunya keuntungan yang menjadi tujuan bisnis juga akan mudah dicapai, baik keuntungan finansial maupun keuntungan yang sifatnya non materi, yaitu nilai-nilai yang lahir akibat adanya bisnis yang beretika. Inilah sharia marketing (Arifin, 2009: 1).

Sharia marketing adalah sebagai sebuah disiplin bisnis strategi yang mengarah pada proses penciptaan, penawaran dan perubahan nilai dari seorang produsen atau perusahaan atau perorangan kepada orang lain, yang dalam keseluruhan prosesnya sesuai dengan akad dan prinsip-prinsip bisnis dalam Islam (Rivai, 2013: 35).

Bisnis Islami pada hakikatnya selalu memegang asas keadilan dan keseimbangan. Selain itu juga telah dicontohkan aplikasi nilai-nilai Islam dalam mengelola bisnis oleh Nabi Muhammad SAW agar berhasil baik di dunia maupun di akhirat. Nilai-nilai bisnis Islam telah menjadi tren dalam mengendalikan tujuan dan harapan ekonomi dalam jangka panjang.Dengan mengedepankan kejujuran, kepercayaan, keadilan, professional dan komunikasi yang baik, maka muncul spirit moral dalam bisnis sehingga melahirkan bisnis atau usaha yang diberkahi (Malahayati, 2010: 61). 
Sharia marketing dalam sebuah lembaga sangat menentukan keberlangsungan sebuah lembaga itu sendiri. Lembaga atau perusahaan yang menjalankan bisnisnya sesuai dengan syariat Islam adalah lembaga yang dalam melakukan segala kegiatan usahanya tidak melanggar aturan Islam yaitu tidak berhubungan dengan bisnis judi, riba dan produk-produk haram, karena itu diperlukan lembaga-lembaga perbankan yang Islami sehingga umat Islam dapat menyalurkan investasi sesuai syariat Allah. Seiring dengan diperlukannya lembaga-lembaga perbankan yang Islami ini membuat setiap orang maupun kelompok mendirikan lembaga yang bergerak di bidang jasa keuangan syariah. Hal ini tentunya menjadi sebuah persaingan diantara lembagalembaga keuangan syariah tersebut. Agar suatu lembaga keuangan syariah dapat terus dan memenangkan persaingan, lembaga dituntut untuk mengadakan perbaikan dan peningkatan dibidang pemasaran.

Perbaikan dan peningkatan dibidang pemasaran harus dilaksanakan secara terencana. Dengan kata lain lembaga keuangan syariah harus menentukan strategi pemasaran yang tepat. Perubahan lingkungan perusahaan terutama faktor pesaing yang mampu menghasilkan produk yang sama menyebabkan banyak lembaga keuangan yang berorientasi pada anggota. Lembaga keuangan yang berorientasi pada anggota hendaknya selalu mengetahui apa yang dibutuhkan dan diinginkan oleh para anggotanya, sehingga anggota tidak hanya terpuaskan karena kebutuhan dan keinginannya terpenuhi, akan tetapi menjadi loyal dan kembali pada lembaga keuangan tersebut.

KSPPS BMT Walisongo Semarang merupakan koperasi yang kegiatan usahanya bergerak di bidang pembiayaan, investasi dan simpanan sesuai pola bagi hasil syariah. Lembaga ini memanfaatkan dana dari masyarakat kemudian menyalurkannya kembali kepada masyarakat dalam bentuk pembiayaan sesuai dengan kaidahkaidah syariat Islam. Di lain sisi keberadaan KSPPS BMT Walisongo Semarang ini merupakan alternatif bagi masyarakat dalam bertransaksi baik simpanan maupun pembiayaan. Pola pemasaran yang dilakukan KSPPS BMT Walisongo Semarang merupakan pola pemasaran yang menekankan kepada semua kalangan masyarakat, baik dari tingkat pendapatan, tempat tinggal, usia, pekerjaan dan jenis kelaminnya, diharapkan dapat memberikan gambaran mengenai loyalitas anggota terhadap produk KSPPS BMT Walisongo Semarang. Loyalitas anggota dapat dilihat dari perkembangan anggota berikut ini:

Tabel 1. Data Anggota di KSPPS BMT Walisongo Semarang:

\begin{tabular}{lrr}
\hline \multicolumn{1}{c}{ Nama Produk } & Tahun 2015 & Tahun 2016 \\
\hline Simpanan & & \\
Simpanan Sukarela & 1.803 & 2.100 \\
Simpanan Berjangka & 98 & 100 \\
Pembiayaan & & \\
Mudharabah & - & - \\
bai'bitsaman ajil (BBA) & 220 & 184 \\
Murabahah & 107 & 85 \\
\hline JUMLAH & $\mathbf{2 . 2 2 8}$ & $\mathbf{2 . 4 6 9}$ \\
\hline
\end{tabular}

Sumber: Rapat Akhir Tahunan KSPPS BMT Walisongo Selasa, 14 Maret 2017 
Tabel diatas menunjukan produk simpanan sukarela pada tahun 2015 berjumlah 1.803 anggota dan pada tahun 2016 meningkat jumlahnya menjadi 2.100 anggota. Produk Simpanan berjangka pada tahun 2015 berjumlah 98 anggota dan pada tahun 2016 berjumlah 100 anggota. Untuk produk pembiayaan mudharabah pada tahun 2015 dan 2016 belum ada jumlah anggotanya. Produk bai'bitsaman ajil (BBA) pada tahun 2015 berjumlah 220 anggota dan pada tahun 2016 mengalami penurunan jumlah anggota sebanyak 184 anggota. Produk murabahah juga mengalami penurunan anggota pada tahun 2015 sebanyak 107 anggota pada tahun 2016 menjadi 85 anggota. Hal ini tidak terlepas dari pelayanan KSPPS BMT Walisongo Semarang yang diberikan kepada anggotanya. Pelayanan ini sangat berpengaruh terhadap kepuasan anggota yang nantinya akan menjadikan anggota loyal terhadap KSPPS BMT Walisongo Semarang tersebut.

Loyalitas anggota merupakan hal yang sangat penting kaitannya dengan pengembangan usaha. Anggota yang mempunyai loyalitas yang tinggi akan senantiasa menggunakan produk atau jasa yang disediakan perusahaan dan tidak akan terpengaruh kepada jasa yang ditawarkan pihak lain. Loyalitas anggota juga dipengaruhi oleh kualitas pelayanan. Kualitas pelayanan sangat penting kaitannya dengan eksistensi dan perkembangan keberhasilan perusahaan jasa. Kualitas pelayanan akan berpengaruh pada kepuasan anggota yang pada akhirnya akan berdampak pada loyalitas anggota pada penyedia jasa tersebut (Tjiptono, 2012: 74). Dimana loyalitas anggota merupakan aspek strategis dalam memenangkan persaingan dan mempertahankan citra perusahaan di masyarakat luas.

Untuk membuat anggota menjadi loyal maka dibutuhkan suatu taktik marketing agar melayani anggota dengan cara memuaskan melalui elemen 4 P yaitu:product (produk), promotion (promosi), price (harga) dan place (tempat). Hal ini untuk melihat yang dirasakan anggota tentang kualitas produk atau jasa layanan lembaga keuangan syariah dan kualitas produk atau jasa layanan seperti apa yang diinginkan oleh pelanggan (Kotler dan Susanto, 2001: 541). Untuk mengidentifikasi pemenuhan tingkat kualitas harapan para konsumen tidak mudah, karena sekali konsumen dapat merasakan kualitas produk atau jasa layanan yang tinggi baik dari perusahaan maupun dari pesaingnya, maka mereka akan mengharapkan pengalaman yang sama akan berulang. Apabila suatu perusahaan dapat mengidentifikasi kualitas produk atau jasa layanan sesuai dengan harapan konsumen, sudah barang tentu hal ini akan menimbulkan kepuasan pada konsumennya, dengan kata lain penawaran kualitas produk atau jasa layanan yang baik dapat mempengaruhi pemakaian ulang produk ataupun jasa perusahaan. Kualitas produk atau jasa layanan yang baik dalam menciptakan kepuasan konsumen memberikan berbagai manfaat, diantaranya memberikan dasar yang kuat sehingga terciptanya kesetiaan anggota yang pada akhirnya disebut sebagai loyalitas anggota. Loyalitas pada suatu perusahaan akan menghalangi pelanggan agar tidak terpengaruh dari perusahaan lain. Di samping itu, loyalitas yang tinggi juga menjadi pendorong untuk melakukan pembelian ulang serta mengajak orang lain untuk menggunakan jasa tersebut (Cholifah, 2010: 11). Berdasarkan paparan diatas, maka penelitian ini akan menguji bagaimana pengaruh sharia marketing terhadap loyalitas nasabah pada KSPPS BMTWalisongo Semarang? 


\section{LANDASAN TEORI}

\section{Sharia Marketing}

Makna harfiah syariah adalah jalan menuju sumber kehidupan. Secara etimologi syariah berasal dari bahasa arab syara'a, yasyra'u, syar'an wasyari'atan yang berarti jalan ketempat air. Kata ini kemudian dikonotasikan oleh bangsa arab dengan jalan yang lurus yang harus dituntut. Sedangkan menurut terminologi syariah berarti jalan yang ditetapkan Tuhan yang membuat manusia harus mengarahkan hidupnya untuk mewujudkan kehendak Tuhan agar hidupnya bahagia di dunia dan akhirat. Makna ini meliputi seluruh panduan Allah kepada hamba-Nya.

Syariah juga diartikan sebagai jalan lurus atau thariqatun mustaqimatun (Nasution, 2013: 51), sebagaimana diisyaratkan dalam Al-Qur'an surat Al-Jatsiyah ayat 18:

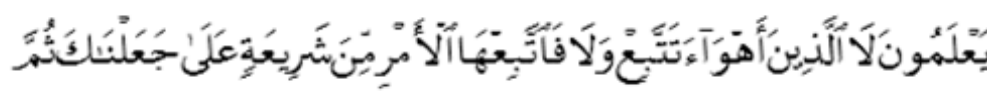

"Kemudian kami jadikan kamu berada di atas suatu syariat (peraturan) dari urusan (agama) itu, maka ikutilah syariat itu dan janganlah kamu ikuti hawa nafsu orang-orang yang tidak mengetahui". (QS Al-Jatsiyah: 18).

Jadi sharia marketing sendiri merupakan sebuah disiplin bisnis strategis yang mengarahkan proses penciptaan, penawaran, dan perubahan nilai dari seorang produsen atau perusahaan atau perorangan kepada orang lain dan dalam keseluruhan prosesnya sesuai dengan akad serta prinsip-prinsip bisnis dalam Islam.

Dalam sharia marketing seluruh proses tidak boleh ada yang bertentangan dengan prinsip-prinsip Islami. Selama proses bisnis ini dapat dijamin atau tidak terjadi penyimpangan terhadap prinsip Islam, maka setiap transaksi apa pun dalam pemasaran diperbolehkan.

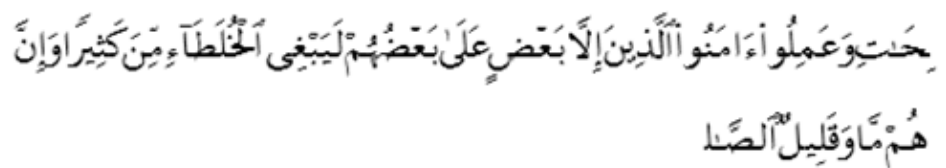

Allah mengingat-

kan agar senantiasa menghindari perbuatan zalim dalam berbisnis termasuk dalam proses penciptaan, penawaran, dan proses perubahan nilai dalam pemasaran (Amrin, 2007: 2), sebagai firman Allah dalam surat Shaad ayat 24 :

"Sesungguhnya kebanyakan dari orang-orang yang bersyarikat (berbisnis) itu sebagian dari mereka berbuat zalim kepada sebagian yang lain, kecuali orang beriman dan mengerjakan amal saleh, dan amat sedikit mereka itu".

\section{P (Product, Price, Place dan Promotion)}

Dalam sharia marketing terdapat unsur strategi pemasaran yang sering kita kenal sebagai bauran pemasaran atau marketing mix.Bauran pemasaran merupakan alat bagi pemasar yang terdiri atas berbagai unsur suatu program pemasaran yang perlu dipertimbangkan agar implementasi strategi pemasaran dan positioning yang ditetapkan dapat berjalan dengan sukses. Perencanaan pemasaran biasanya disusun berdasarkan $4 \mathrm{P}$ yaitu product (produk), price (harga), place (tempat), promotion (promosi) (Lupiyoadi dan Hamdani,2006: 70). 


\section{Product (produk)}

Produk adalah barang atau jasa yang bisa ditawarkan di pasar untuk mendapatkan perhatian, permintaan atau konsumsi yang dapat memenuhi keinginan atau kebutuhan. Dalam pembuatan produk harus memperhatikan nilai kehalalan, bermutu, bermanfaat dan berhubungan dengan kebutuhan hidup manusia. Dalam jual beli, suatu produk dilarang mengandung unsur ketidakjelasan (gharar) karena akan menimbulkan potensi terjadinya penipuan dan ketidakadilan pada salah satu pihak.

Persyaratan mutlak ada dalam sebuah produk yang akan diperjual belikan, baik berupa barang maupun jasa harus memenuhi kriteria halal. Hal itu penting sekali terkait dengan apa yang dibutuhkan konsumen. Selain itu pula untuk menghindari adanya usaha penipuan, dengan adanya standar halal dan kualitas yang terjamin tentu konsumen dengan sendirinya akan yakin dengan apa yang akan dibelinya dan diinginkannya. Bahkan kriteria halal merupakan syarat utama dan mutlak bagi persaingan bisnis dalam perspektif bisnis Islami.

Nabi Muhammad dalam praktek elemen produk selalu menjelaskan kualitas barang yang dijualnya. Kualitas produk yang dipesan oleh pelanggan selalu sesuai dengan barang yang diserahkan. Seandainya terjadi ketidakcocokan, beliau mengajarkan bahwa pada pelanggan ada hak khiyar yaitu dengan cara membatalkan jual beli.

\section{Price (harga)}

Harga dapat diartikan sebagai ekspresi dari sebuah nilai, dimana nilai tersebut menyangkut kegunaan dan kualitas produk, citra yang terbentuk melalui iklan dan promosi, ketersediaan produk melalui jaringan distribusi dan layanan yang menyertainya (Gunara \& Sudibyo, 2007: 49).

Dalam persaingan dunia bisnis harga merupakan sesuatu yang penting. Dalam hal ini harga yang dipatok harus benar-benar kompetitif, antara pebisnis satu dengan yang lainnya tidak boleh menggunakan cara-cara yang saling merugikan pebisnis lainnya.

Penentuan harga dalam ekonomi syariah didasarkan atas mekanisme pasar, yakni harga ditentukan berdasarkan kekuatan permintaan dan penawaran atas azas sukarela ('an taradhim), sehingga tidak ada satu pihak pun yang teraniaya. Dengan syarat, sebaiknya kedua belah pihak yang bertransaksi mengetahui mengenai produk dan harga di pasaran. Dalam menentukan harga yang harus diperhatian adalah penentuan persaingan sebagai batas atas dan biaya (cost) sebagai batas bawah. Harga yang ditetapkan tidak boleh lebih tinggi dari harga yang ditawarkan oleh pesaing atau lebih rendah dari biaya yang dikeluarkan.

\section{Place (tempat)}

Place juga dapat diartikan sebagai pemilihan tempat atau lokasi usaha. Penentuan tempat usaha yang mudah terjangkau dan terlihat akan memudahkan bagi konsumen untuk mengetahui, mengamati dan memahami dari suatu produk atau jasa yang ditawarkan. Penentuan tempat di dasarkan atas jenis usaha atau produk yang diciptakan. Semakin strategis tempat usaha maka kemungkinan juga akan semakin membawa keuntungan, selain itu yang harus diperhatikan dalam mengelola tempat berbisnis adalah baik, sehat, bersih, aman dan nyaman. Hal-hal tersebut penting sekali untuk dipenuhi guna menarik minat konsumen untuk melakukan transaksi bisnis 
dengan kita. Islam juga memberikan satu aturan bahwa tempat bisnis harus dijauhkan dari hal-hal yang diharamkan, semisal memasang gambar-gambar porno, menjual minuman keras, serta hal-hal lain yang sangat dilarang agama hanya dengan tujuan hanya menarik konsumen.

\section{Promotion (promosi)}

Promosi merupakan kegiatan-kegiatan yang secara aktif dilakukan perusahaan untuk mendorong konsumen membeli produk yang ditawarkan. Dalam melakukan promosi perusahaan atau lembaga harus memperhatikan nilai-nilai kejujuran dan menjauhi penipuan. Media dan sarana yang digunakan harus sesuai dengan syariah.

\section{Loyalitas}

Secara harfiah loyalitas dapat diartikan sebagai suatu kesetiaan. Kesetiaan ini timbul tanpa adanya paksaan, tetapi timbul dari kesadaran sendiri pada masa lalu atau merupakan sikap pendukung yang menguatkan kepercayaan banyak orang. Loyalitas berhubungan dengan kesetiaan dan komitmen jangka panjang (Abdullah, 2011: 54). Kesetiaan adalah komitmen yang kuat untuk kembali membeli atau pengulangan pembelian pada produk dan jasa yang di suka secara konsisten dimasa datang. Kesetiaan dan kesediaan konsumen untuk membeli suatu produk secara terus menerus pada pengecer yang sama dapat terjadi apabila konsumen merasa puas dengan kinerja perusahaan.

Menurut kotler dan keller (dalam Budi \& Sihombing, 2010: 68-69) mendefinisikan loyalitas sebagai komitmen mendalam untuk kembali membeli sebuah barang atau jasa di masa yang akan datang tanpa memperdulikan situasi yang terjadi dan adanya akibat dari perpindahan. Konsumen akan kembali membeli suatu produk yang sama ditempat yang sama apabila konsumen merasa kebutuhan dan keinginannya terpuaskan. Hal ini dipengaruhi oleh beberapa faktor antara lain:

a. Harga

b. Penggolongan dan keragaman barang

c. Lokasi penjual yang strategis dan mudah dijangkau

d. Desain fisik toko

e. Servis yang ditawarkan kepada pelanggan

f. Kemampuan tenaga penjual

g. Pengiklanan dan sales promosi di toko

Konsumen yang loyal merupakan inisiable advocate bagi kita. Mereka akan berupaya membela produk kita dan secara sukarela akan merekomendasikan kepada orang lain.

Pemahaman loyalitas anggota sebenarnya tidak hanya dilihat dari transaksinya saja. Ada beberapa ciri seorang anggota dapat dianggap loyal antara lain:

1. Membicarakan hal-hal positif kualitas jasa XYZ kepada orang lain

2. Merekomendasikan jasa XYZ kepada orang lain

3. Mendorong teman atau relasi bisnis untuk berbisnis dengan XYZ

4. Mempertimbangkan XYZ pilihan pertama dalam membeli atau menggunakan jasa

5. Tidak terpengaruh dengan jasa lain (Lupiyoadi, 2001: 161).

Loyalitas pelanggan merupakan kesetiaan pelanggan terhadap penyedia jasa yang telah memberikan pelayanan kepadanya. Loyalitasdapat diukur dengan tiga in- 
dikator, yaitu:

1. Repeat, yaitu apabila pelanggan membutuhkan barang atau jasa yang disediakan oleh penyedia jasa yang bersangkutan

2. Retention, yakni ia tidak terpengaruh jasa yang ditawarkan oleh pihak lain.

3. Referral, apabila jasa yang diterima memuaskan, maka pelanggan akan memberitahukan kepada pihak lain, dan sebaliknya apabila ada ketidakpuasan atas pelayan yang diterima ia tidak akan bicara pada pihak lain, tapi justru akan memberitahukan layanan yang kurang memuaskan tersebut pada pihak penyedia dana.

Sedangkan loyalitas berdasarkan prilaku pembelian, menurut Griffin dalam Nalau, et al (2012) pelanggan yang loyal merupakan orang yang:

1. Melakukan pembelian ulang secara teratur

2. Membeli antarlini produk dan jasa

3. Mereferensikan kepada orang lain

4. Menunjukkan kekebalan terhadap tarikan dari pesaing.

\section{Kerangka Pemikiran Teoritik}

Sharia Marketing (X)

- Product (produk)

- Price (harga)

- Place (tempat)

- Promotion(promosi)
Loyalitas Anggota (Y)

- Membicarakan hal-hal positifnya

- Merekomendasikan kepada orang lain

- Mendorong teman atau relasi untuk berbisnis dengan lembaga itu

- Mempertimbangkan sebagai pilihan pertama

- Tidak terpengaruh pada jasa lain

Gambar 1. Kerangka Berpikir

\section{METODE PENELITIAN}

\section{Jenis dan Sumber Data}

Data adalah bahan keterangan tentang sesuatu objek penelitian yang diperoleh dilokasi penelitian (Bungin, 2006: 119). Adapun jenis penelitian ini dikategorikan sebagai penelitian lapangan, karena data yang diperoleh dari hasil pengamatan langsung pada anggota KSPPS BMT Walisongo Semarang. rikut:

Adapun sumber data yang digunakan dalam penelitian ini adalah sebagai be-

1. Data primer adalah data yang dikumpulkan dan diolah sendiri oleh suatu organisasi atau perorangan langsung dari objeknya. Data ini diperoleh langsung dari penyebaran angket yang diberikan kepada nasabah KSPPS BMT Walisongo Semarang sebagai responden yang terpilih untuk dijadikan penelitian.

2. Data sekunder adalah data yang diperoleh dalam bentuk yang sudah jadi, sudah dikumpulkan dan diolah oleh pihak lain (Santoso \& Tjiptono, 2001: 59). Data sekunder dalam penelitian ini diperoleh dari literatur-literatur, jurnal penelitian dan data tentang KSPPS BMT Walisongo Semarang, yaitu men- 
genai gambaran umum tentang perusahaan.

\section{Populasi dan Sampel}

Populasi merupakan keseluruhan kelompok orang, kejadian, atau hal-hal yang menarik bagi peneliti untuk ditelah. Dalam penelitian ini yang menjadi populasi adalah semua nasabah KSPPS BMT Walisongo Semarang yang berjumlah 2.469 anggota.

Sampel merupakan bagian atau subset dari populasi yang terdiri dari anggotaanggota populasi yang terpilih (Zulganef, 2008: 133). Sampel diambil dalam penelitian sebagai pertimbangan efesiensi dan mengarah pada sentralisasi permasalahan dengan memfokuskan pada sebagian dari populasinya (Subagyo,1997: 29). Jumlah sampel dalam penelitian ini ditentukan dengan menggunakan rumus Slovin dengan tingkat kesalahan yang ditoleransi sebesar $10 \%$.

$$
n=\frac{N}{1+N e^{2}}
$$

Dimana :

$\mathrm{n}$ : jumlah sampel minimal

$\mathrm{N}$ : jumlah populasi

e : presentase kelonggaran ketelitian karena kesalahan pengambilan sampel.

$$
\begin{aligned}
n & =\frac{2.469}{1+2.469(0,1)^{2}} \\
& =96,11
\end{aligned}
$$

Berarti jumlah sampel minimum yang digunakan adalah 96 anggota dibulatkan menjadi 100 anggota.

Penelitian ini menggunakan metode non probability sampling yaitu teknik pengambilan sampel dimana tiap anggota populasi tidak mempunyai kesempatan yang sama untuk dijadikan sampel. Dengan demikian, tehnik pengambilan sampel ini akan memilih anggota populasi yang dapat memberikan informasi secara maksimal atau yang paling mudah ditemui. Dalam penelitian ini, peneliti menggunakan responden yang dengan mudah dapat dijumpai dengan kriteria-kriteria tertentu atau yang sering disebut sebagai purposive sampling (Suliyanto, 2009: 100).

\section{Metode Pengumpulan data}

Metode pengumpulan data merupakan langkah yang dapat menentukan berhasil tidaknya suatu penelitian. Oleh karena itu pemilihan metode pengumpulan data yang tepat akan memperoleh data yang relevan dan akurat. Metode pengumpulan data dalam penelitian ini yaitu :

1. Kuesioner

Kuesioner merupakan suatu alat pengumpul informasi dengan cara menyam- 
paikan sejumlah pertanyaan tertulis untuk dijawab secara tertulis pula oleh responden. Kuesioner merupakan teknik pengumpulan data yang efisien bila peneliti tahu dengan pasti variabel yang akan diukur dan tahu apa yang bisa diharapkan dari responden (Zuriah, 2005: 182). Dalam penelitian ini kuesioner dibagikan kepada anggota yang termasuk didalam sampel yang berjumlah 100 anggota. Disini anggota diberikan daftar pertanyaan-pertanyaan dan berkewajiban untuk menjawab sesuai dengan alur yang telah ditentukan peneliti.

2. Dokumentasi

Dokumentasi digunakan untuk pengumpulan data berupa data tertulis yang mengandung keterangan dan penjelasan serta pemikiran tentang fenomena yang masih aktual dan sesuai dengan masalah penelitian. Misalnya berupa arsip-arsip, buku-buku catatan yang lainnya yang berhubungan dengan penelitian ini (Muhammad, 2008: 152). Dokumentasi yang digunakan yaitu yang berhubungan dengan profil tentang KSPPS BMT Walisongo Semarang.

\section{Metode Analisis Data}

Metode yang digunakan untuk menganalisis hubungan antara variable independen dengan variable dependen adalah metode regresi linier sederhana sebagai berikut:

\section{$\mathbf{Y}=\mathbf{a}+\mathbf{b} \mathbf{X}$}

Dimana:

$\mathrm{Y}=$ Loyalitas anggota KSPPS BMT Walisongo Semarang

$\mathrm{a}=$ Nilai konstanta

$\mathrm{b}=$ Koefisien regresi

$\mathrm{X}=$ sharia marketing

\section{HASIL PENELITIAN DAN PEMBAHASAN}

\section{Koefisien Determinasi}

Koefisien determinasi memiliki fungsi untuk menjelaskan sejauh mana kemampuan variabel independen (sharia marketing) terhadap variabel dependen (loyalitas) dengan melihat $\mathrm{R}$ square.Hasil koefisien determinasi dapat dilihat pada tabel di bawah ini:

Tabel 2. Uji Pengaruh

\begin{tabular}{lcrrr}
\hline \multicolumn{5}{c}{ Model Summary $^{\mathbf{b}}$} \\
\hline Model & $\mathrm{R}$ & R Square & Adjusted R Square & Std. Error of the Estimate \\
\hline 1 &, $552^{\mathrm{a}}$ &, 305 &, 298 &, 31358 \\
\hline a. Predictors: (Constant), sharia marketing & & \\
b. Dependent Variable: loyalitas anggota & \\
\hline
\end{tabular}

Sumber : Data Primer yang diolah, 2017

Hasil analisis data pada variabel loyalitas terlihat bahwa $\mathrm{R}$ square sebesar 0.305 atau $30,5 \%$. Hal ini menunjukkan bahwa variabel independen yaitu sharia 
marketing hanya mampu menjelaskan variabel dependen sebesar 30,5\%, sisanya $69,5 \%$ dijelaskan oleh variabel lain yang tidak ada atau tidak diperhitungkan dalam analisis penelitian.

\section{Uji Parsial (t test)}

Uji parsial ini memiliki tujuan untuk menguji atau mengkonfirmasi hipotesis secara individual antara variabel independen (sharia marketing) secara parsial mempunyai pengaruh yang signifikan terhadap variabel dependen (loyalitas).Hasil $\mathrm{t}$ test ini dijelaskan pada tabel berikut ini:

Tabel 3. Uji Parsial ( $\mathrm{t}$ test)

\begin{tabular}{|c|c|c|c|c|c|c|c|c|}
\hline & & & Coeffic & & & & & \\
\hline & \multirow{2}{*}{ Model } & \multicolumn{2}{|c|}{$\begin{array}{r}\text { Unstandardized Coef- } \\
\text { ficients } \\
\end{array}$} & $\begin{array}{r}\text { Standardized } \\
\text { Coefficients }\end{array}$ & \multirow{2}{*}{$t$} & \multicolumn{3}{|c|}{ Collinearity Statistics } \\
\hline & & B & Std. Error & Beta & & & $\begin{array}{r}\text { Tole } \\
\text { rance }\end{array}$ & VIF \\
\hline \multirow[t]{2}{*}{1} & (Constant) & 1,419 & ,434 & & 3,266 &, 002 & & \\
\hline & $\begin{array}{l}\text { Sharia } \\
\text { Marketing }\end{array}$ & 661 & ,101 & ,552 & 6,558 &, 000 & 1 & 1 \\
\hline
\end{tabular}

a. Dependent Variable: Loyalitas Anggota

Sumber : Data Primer yang diolah, 2017

Dari tabel di atas, dapat diketahui dari hasil analisis regresi dapat di peroleh koefisien untuk variabel sharia marketing sebesar 0,661 atau 66,1\% dengan konstanta sebesar 1,419 sehingga model persamaan regresi yang diperoleh adalah sebagai berikut:

$$
\mathrm{Y}=1,419+0,661 \mathrm{X}
$$

Hasil analisis dengan menggunakan bantuan program SPSS versi 19 diperoleh hasil bahwa pengaruh sharia marketing terhadap loyalitas anggota KSPPS BMT Walisongo Semarang, menunjukkan nilai thitung sebesar 6,558 dan $\mathrm{p}$ value (sig) sebesar 0,000 yang di bawah alpha $5 \%$. Artinya bahwa sharia marketing berpengaruh terhadap loyalitas anggota KSPPS BMT Walisongo Semarang.

Nilai beta dalam unstandardized coefficient variabel sharia marketing menunjukkan angka sebesar 0,661, yang artinya jika variabel sharia marketing ditingkatkan satu satuan maka loyalitas anggota akan meningkat sebesar 66,1\%. Hal ini menunjukkan bahwa semakin meningkatnya sharia marketing maka anggota akan memiliki loyalitas yang tinggi pula pada pemasaran yang dilakukan oleh KSPPS BMT Walisongo Semarang.

\section{PEMBAHASAN}

Dari hasil pengujian yang telah dilakukan terbukti bahwa sharia marketing memiliki pengaruh yang signifikan terhadap loyalitas anggota pada KSPPS BMT Walisongo Semarang ( $\mathrm{p}$ value $<0,05)$. Sharia marketing merupakan faktor yang perlu diperhitungkan dalam loyalitas anggota. Semakin baik sharia marketing yang 
dilakukan maka akan semakin menunjukkan sikap loyal anggota terhadap KSPPS BMT Walisongo Semarang. Ini ditunjukkan dengan jawaban responden pada masing-masing pernyataan dengan mayoritas setuju dan sangat setuju meskipun ada beberapa item pernyataan yang dijawab ragu-ragu dan tidak setuju. Keempat dimensi dalam sharia marketing yang terdiri dari produk, tempat, harga dan promosi memiliki pengaruh terhadap loyalitas anggota.Angota menyatakan produknya halal, berkualitas, bermanfaat dan tidak ada unsur penipuan.Untuk harga, seperti bagi hasil dan biaya-biaya adalah kesepakatan antara kedua belah pihak yaitu antara anggota dan lembaga. Sedangkan untuk tempat, anggota menyatakan tempatnya strategis. Lembaga juga memberikan kemudahan dengan mendatangi anggota yang ingin melakukan simpanan maupun pembiayaan. Untuk masalah promosi anggota juga menyatakan bahwa promosi yang dilakukan itu tidak berlebih-lebihan, apa adanya dan tidak ada unsur penipuan. Keempat dimensi dalam sharia marketing sama-sama memiliki pengaruh yanng positif dan signifikan terhadap loyalitas anggota. Namun dalam penelitian ini aspek produk memiliki pengaruh yang lebih tinggi dibandingkan dengan aspek dimensi sharia marketing yang lain. Produk yang halal menjadikan anggota tidak ragu-ragu dalam menggunakan layanan jasa keuangan pada lembaga keuangan tersebut. Produk yang bermutu dan bermanfaat juga menjadikan anggota lebih senang karena produk yang digunakan bagus dan dapat bermanfaat dalam pengembangan perekonomiannya. Produk yang jelas dan tidak mengandung unsur penipuan merupakan hal yang sangat penting bagi anggota karena anggota dengan jelas mengetahui karakter produk tersebut sejak awal sehingga anggota tidak merasa kecewa dan tidak dirugikan.

Loyalitas diartikan sebagai kesetiaan anggota terhadap penyedia jasa yang telah memberikan pelayanan kepadanya. Dalam penelitian ini, dapat diketahui bahwa pada variabel loyalitas masing-masing item pernyataan sebagian besar dijawab setuju atau dapat diambil kesimpulan, mayoritas responden tidak keberatan membicarakan hal-hal positif tentang kualitas jasa KSPPS BMT Walisongo Semarang kepada orang lain, tidak keberatan untuk merekomendasikannya kepada orang lain, tidak keberatan menjadikan KSPPS BMT Walisongo Semarang sebagai pilihan pertama dalam menggunakan jasa keuangan dan merasa puas menggunakan produk KSPPS BMT Walisongo Semarang serta tidak terpengaruh dengan tawaran produk jasa keuangan lainnya. Sharia marketing yang dilakukan oleh suatu lembaga menjadi sangat penting untuk diperhatikan. Jika sharia marketing memperhatikan semua kebutuhan dan keinginan anggota, maka anggota akan merasa puas dan akan loyal terhadap lembaga tersebut.

Hasil analisis regresi yang dilakukan dalam penelitian ini, antara masing-masing variabel independen (sharia marketing) dan variabel dependen (loyalitas) dapat dijelaskan sebagai berikut:

Untuk mengetahui seberapa besar kontribusi variabel sharia marketing dalam upaya mempengaruhi variabel loyalitas dapat diwakili oleh koefisien determinasi. Hasil koefisien determinasi dari variabel sharia marketing yang dinotasikan dalam besarnya R square adalah 0.305 atau 30.5\%, hal ini berarti sebesar 30,5\% kemampuan model regresi dari penelitian ini dalam menjelaskan variabel dependen. Artinya $30,5 \%$ variabel sharia marketing dapat menjelaskan variansi variabel dependen loyalitas. Sedangkan sisanya $69,5 \%$ dipengaruhi oleh variabel-variabel lain yang tidak 
diperhitungkan dalam analisis penelitian ini.

Dari hasil uji t atau pengujian secara individual yang dilakukan terbukti bahwa variabel sharia marketing berpengaruh signifikan terhadap loyalitas anggota KSPPS BMT Walisongo Semarangkarena hasil signifikansinya lebih kecil dari probabilitas signifikan 5\% atau 0,05. Hal ini ditunjukkan dengan koefisien regresi sebesar 0,661 dengan tingkat signifikan 0,000 (lebih kecil dari 0,05).

Dari data tersebut juga dapat diketahui hasil analisis regresi dan dapat diperoleh koefisien untuk variabel sharia marketing (X) sebesar 0,661 dengan kostanta sebesar 1,419 sehingga model persamaan regresiyang diperoleh adalah sebagai berikut :

\section{$Y=1,419+0,661 X$}

Persamaan ini dapat diinterprestasikan sebagai berikut :

Konstanta (a) : 1,419, nilai konstanta bernilai positif

Koefisien b : 0,661, koefisien variabel sharia marketing bernilai positif artinya, pengaruh sharia marketing terhadap loyalitas anggota adalah bernilai positif dan cukup kuat. Jika skor sharia marketing meningkat, maka loyalitas anggota akan semakin tinggi.

Berdasarkan pemaparan di atas sudah jelas, hasil penelitian menunjukkan adanya pengaruh sharia marketing terhadap loyalitas anggota KSPPS BMT Walisongo Semarang. Adanya temuan penelitian ini diharapkan dapat membantu pengelola lembaga keuangan syariah bisa memenuhi kebutuhan dan keinginan para anggotanya yang akhirnya akan menimbulkan anggota merasa puas dan menjadi loyal terhadap lembaga tersebut.

\section{PENUTUP}

Dengan melihat hasil penelitian yang telah dibahas, maka dapat disimpulkan bahwa variabel $(\mathrm{X})$ sharia marketing mempunyai pengaruh yang signifikan terhadap variabel (Y) loyalitas anggota KSPPS BMT Walisongo Semarang. Hal ini ditunjukkan dengan thitung $(6,558)$ dan $\mathrm{p}$ value (sig) sebesar 0,000 di bawah $5 \%$ yang artinya sharia marketing mempunyai andil dalam mempengaruhi loyalitas anggota KSPPS BMT Walisongo Semarang. Keempat dimensi dalam sharia marketing sama-sama memiliki pengaruh yang positif dan signifikan terhadap loyalitas anggota. Namun dalam penelitian ini produk yang lebih memiliki pengaruh yang besar terhadap loyalitas anggota.

\section{Saran}

Berdasarkan hasil penelitian yang di peroleh, maka dapat disarankan sebagai berikut:

\section{Bagi KSPPS BMT Walisongo Semarang}

Bagi pihak lembaga, hendaknya lebih giat dalam memasarkan produknya berdasarkan prinsip-prinsip syariah yang disesuaikan dengan kebutuhan dan keinginan anggotanya. Lembaga harus tanggap dengan keadaan lingkungan sekitar agar me- 
ningkatkan dan dapat melakukan perbaikan dibidang pemasaran sehingga anggota akan merasa puas karena kebutuhan dan keinginannya dapat terpenuhi dan menjadi loyal serta tidak akan terpengaruh dengan produk yang ditawarkan oleh lembaga keuangan lainnya.

2. Bagi Peneliti Selanjutnya

Bagi peneliti selanjutnya, hendaknya untuk memperluas penelitian sehingga diperoleh informasi yang lebih lengkap tentang faktor-faktor yang mempengaruhi loyalitas.

\section{DAFTAR PUSTAKA}

Abdullah, M. (2011). Wirausaha Berbasis Syariah. Banjarmasin: Antasari Press.

Alma, B., \& Donni, J, P. (2009). Manajemen Bisnis Syariah. Bandung: Alfabeta.

Amrin, A. (2007). Strategi Pemasaran Asuransi Syariah. Jakarta: PT Grasindo.

Arifin, J. (2009). Etika Bisnis Islami. Semarang: Walisongo Press.

Budi, R., \& Sihombing, S. (2010). Hubungan Kepantasan Harga, Kepuasan Pelanggan, Loyalitas dan Harga yang dapat di terima: Studi Empiris pada Perusahaan Jasa. Jurnal Ekonomi Bisnis, 11(1).

Bungin, B. (2006). Metode Penelitian Kuantitatif. Jakarta: Kencana.

Cholifah. (2010). Pengaruh Bauran Pemasaran terhadap Loyalitas Pelanggan pada Butik Busana Muslim di Kota Semarang, IAIN Walisongo.

Gunara, T. \& Sudibyo, U.H. (2007). Marketing Muhammad SAW. Bandung:CV Multi Trust Creative Service.

Hasan, A. (2009). Manajemen Bisnis Syariah. Yogyakarta: Pustaka Pelajar.

Kotler, P., \& Susanto, A.B. (2001). Manajemen Pemasaran di Indonesia. Jakarta: Salemba Empat.

Lupiyoadi, R. (2001). Manajemen Pemasaran Jasa: Teori dan Praktek.Jakarta: PT Salemba Emban Patria.

Lupiyoadi, R. \& Hamdani. (2006). Manajemen Pemasaran Jasa. Jakarta:Salemba Empat.

Malahayati. (2010). Rahasia Sukses Bisnis Rasulullah. Yogyakarta: Jogja Great Publisher (Anggota Ikapi).

Muhammad. (2008). Metode Penelitian Ekonomi Islam. Jakarta: PT Raja Grafindo Persada.

Nalau, A., Hudayah, S. \& Wasil, M. (2012). Brand Image Terhadap Loyalitas Pelanggan J.Co Donuts \& Coffee Di Plaza Mulia Samarinda. Jurnal Ekonomi

Nasution, M.S.A. (2013). Filsafat Hukum Islam. Jakarta: PT Raja Grasindo Persada.

Rivai, V. (2013). Islamic Marketing (membangun dan mengembangkan bisnis dengan praktik marketing Rasulullah saw). Jakarta: PT Gramedia Utama.

Santoso, S. \& Tjiptono, F. (2001). Riset Pemasaran konsep dan Aplikasi dengan SPSS. Jakarta: PT Elex Media Komputindo.

Subagyo, P.J. (1997). Metode penelitian. Jakarta: PT Rineka Cipta.

Suliyanto. (2009). Metode Riset Bisnis. Yogyakarta: CV. Andi Offset.

Tjiptono, Fandy. (2012). Pemasaran Strategi. Yogyakarta: Andi Yogyakarta, edisi dua.

Zulganef. (2008). Metode Penelitian Sosial dan Bisnis. Yogyakarta: Graha Ilmu.

Zuriah, N. (2005). Metodologi Penelitian Sosial dan Pendidikan (teori-aplikasi). Jakarta: PT Bumi Aksara. 